Volume 4, No. 3, September - December 2019 ISSN: 2503-4235 (p); 2503-4243 (e)

Shirkah

Journal of Economics and Business 


\section{Shirkah}

Journal of Economics and Business

Vol. 4, No. 3, September-December 2019

ISSN: 2503-4235 (p); 2503-4243 (e)

\section{Editor in Chief}

Fitri Wulandari

\section{Managing Editor}

Jasanta Peranginangin

\section{Editorial Boards}

Abdul Azim Islahi

Islamic Economics Institute, King Abdulaziz University, Saudi Arabia

Abu Umar Faruq Ahmad,

UBD School of Business and Economics Universiti, Brunei Darussalam

Cedomir Nestorovic,

ESSEC Business School Asia Pacific, Singapore

Johan Fischer,

Department of Social Sciences and Business Roskilde Universitetscenter, Denmark Muhamed Zulkhibri,

Islamic Research and Training Institute, Islamic Development Bank, Saudi Arabia M. Kabir Hassan,

Department of Economics and Finance, University of New Orleans, United States Musa Asy'arie,

Faculty of Islamic Economics and Business, IAIN Surakarta, Indonesia

Nunung Nurul Hidayah,

Aston Business School, Aston University, Birmingham, United Kingdom

Saim Kayadibi,

Department of Economics, Kulliyyah of Economics and Management Science,

International Islamic University Malaysia, Malaysia

Shaikh M Ghazanfar,

Departement of Economics, University of Idaho, Russian Federation

Sigit $\mathrm{S}$. Wibowo, 
Department of Management, Faculty of Economics and Business, Universitas Indonesia, Indonesia

Vihang R. Errunza,

Desmarais Global Finance Research Centre, Desautels Faculty and Management, McGill University, Canada

\section{Assistant to Editor \\ M. Endy Saputro \\ M. Zainal Anwar}

Shirkah Journal of Economics and Business is a peer-reviewed journal published three times a year (January-April, May-August and September-December) by Faculty of Islamic Economics and Business, Institut Agama Islam Negeri (IAIN) Surakarta Central Java, Indonesia. The main objective of Shirkah is to offer an academic space of exchange ideas and initiate the increase number of qualified article produced by postgraduate students, practitioners and academicians.

\section{Editorial Office}

Ruang Jurnal Shirkah

Lantai Dasar, Sayap Barat, Fakultas Ekonomi dan Bisnis Islam, IAIN Surakarta

Jln. Pandawa No. 1, Kartasura, Sukoharjo, Jawa Tengah Kode Pos. 57168

Phone (+62271) 781516 Fax: (+62271)782336

E-mail: shirkahjournal@iainsurakarta.ac.id; shirkahiainsurakarta@gmail.com

Website: http://shirkah.or.id/ 


\section{Shirkah}

Journal of Economics and Business

Vol. 3, No. 3, September-December 2018

ISSN: 2503-4235 (p); 2503-4243 (e)

\section{Table of Contents}

\section{Articles}

M. Falikul Isbah

External Influences and Supports to Pesantren's Socio-Economic

Activism in Changing Context

R. Lukman Fauroni

The Economic Community of Pesantren Al-Ittifaq Opposing

Market Capitalism and the Improvement of Competitiveness

M. Musa Al Hasyim

403

Creative Industry Development in Pesantren Tebuireng

Kuat Ismanto

N. Nasrullah

429

Multiplier Effects of Pesantren Walindo

Mustaghfiroh Rahayu

455

Social Embeddedness and Economic Behaviour in Pesantren Mlangi

Helmi Haris

Muhammad Nashirudin

481

Lombok as an Indonesian Halal Travel Destination 


\title{
The Economic Community of Pesantren Al-Ittifaq Opposing Market Capitalism and the Improvement of Competitiveness
}

\author{
R Lukman Fauroni \\ Institut Agama Islam Negeri (IAIN) Surakarta \\ lukmanf9@gmail.com
}

\begin{abstract}
This study aims to elaborate the solution the pesantren economic community takes in dealing with the penetration of market capitalism in competitive era. This case study was conducted in Pesantren Al Ittifaq Bandung. Pesantren can successfully build a strong economic community through integrated education implementation including: role modeling, facilitation, empowerment, and economic culturing in social capital-based community. This article concluded that high consciousness of cooperation can improve competitiveness and be an appropriate strategy to oppose market capitalism penetration. The community's capital asset leads to bargaining position and independence in partnership cooperation thereby can be beneficial and results in welfare.
\end{abstract}

Keywords: pesantren, economic community, social capital, capital asset, cooperation, welfare

\section{Introduction}

Pesantren is a multifunction and relatively dynamic social institution. Such position puts pesantren to be an organic power that can activate people, including in economic sector. Suwito concluded that a number of pesantrens have had economic development model in various sectors: trade, agriculture, agribusiness, service, cooperative, BMT, and even industry (2008), so do in creative economic development. Kiai, ustadz, and technology resource affects its development significantly 
(Bawono, 2018). Pesantren institution can be empowered in economic culture development gradually, systematically, and in structured manner. It involves firstly identifying potential business; secondly, capitalization; thirdly, improving management capacity; and fourthly, entrepreneurship education and culturing (Widodo, 2016). Economic development in pesantren is essentially the expansion of function in addition to its function in social education sector. Pesantren that has expanded its economic function can be called economic pesantren (Indonesian: pesantren ekonomi).

A number of pesantrens in many areas have had good economic entity for the santri's independence, institutional operation, and community's economic empowerment. Some pesantrens have had superior, high profitable business model impacting on the people's improved welfare. This business model's gain builds on: firstly, integrated education synergy involving pesantren education, economic culturing, leadership, network, experience, role modeling and social capital (local wisdom). Secondly, it also builds on competitive advantage in dealing with economic competition as the consequence of strong consciousness of network economy (Fauroni, 2014).

Economic empowerment in Baitul Mal Wattamwil (BMT UGT) sector, BPRS, cooperative of pondok pesantren (kopontren), garment of Pesantren Sidogiri Pasuruan has booked a 16-trillion asset and become the driver of community economy in East Java and other provinces. Sidogiri Cooperative has been recognized to be one of the best national cooperatives (Kurnia, 2018). Pesantren Al-Amin Kawalu Tasikmalaya developed economy in garment and embroidery industry sectors. Through CV Tjiwulan Bordir and PT Tjiwulan Putra Mandiri, many products it produces have been exported to many countries in West Asia, Africa, and even Europe (Fauroni-Mujahid, 2018). 
The pesantren's success in economic development is faced with market capitalism's penetration power that has resulted in dual morality economy. Market capitalism in third world countries develops in diverse social structures and moral tradition. Dual morality, according to Hefner (2016: 236-7), reveals friendly side on the one hand, and original face on the other hand, not giving justice and welfare. It is well established that the national development cake has not been distributed justly and evenly. In this context, an economic developing strategy is required to eliminate the market capitalism penetration power appropriately. Economic globalization like capitalism has two sides of consequence: good and bad. The easiness of affirming new findings (technology) and various commodities in many hemispheres is the good (positive) side. However, the difficulty of warding off market penetration with capital and technology power is the negative side. It is here that justice market is needed. It is also true for the position of village. On the one hand, village has been marginalized and pressured in market capitalism system (Jati, 2014: 17).

Faced with such situation, the pesantren-based people economy that has had economic entity begins to build economic independence and competitiveness through local or community economic development for the sake of nation's economic independence. Economic independence can restrain the market capitalism penetration rate. Economic independence development initiatives coming from either villager community or pesantren community are expected to create justice market. It is the market not putting community economy to be subordinate but to be partner that has control, as Putnam expects. As a social organization, community can improve the community's efficiency through an organized action as social capital and capital asset (Hefner, 2016: 265).

This article is the follow-up to the author's research on Islam business model in pesantren business entity standing on the value system building 
on ukhuwah (fraternity) epicenter (Fauroni, 2014). Through an ukhuwahs business model, economic development can evolve rapidly, productively, and have high competitiveness. This article will focus on elaborating the economic development aspect in pesantren community, particularly when faced with both national and global economic development.

Economics study in pesantren is generally limited to how the development of management aspect or community's economic empowering strategy by pesantren is, without improving critical consciousness of the market capitalism power "enemy". It is this distinction that is put forward through case study field qualitative research (Stake, 1995) in Pesantren Al Ittifaq Bandung. Techniques of collecting data used were participatory observation, interview, and FGD. This can reveal how the strategy of developing the pesantren community's economy is in dealing with competitiveness and market capitalism penetration by establishing partnership cooperation, improving competitiveness, and impacting on the people's improved welfare.

\section{Al-Ittifaq Corporation}

Pesantren Al-Ittifaq Alam Endah Rancabali is located about 45 $\mathrm{km}$ to the south of West Java province's capital. This pesantren prefers developing an agribusiness-based pesantren economy. This preference builds on the supporting natural and environmental potency. Now AlIttifaq Corporation has become a permanent supplier of vegetable and fruit need for many modern markets in Bandung and Jakarta and a number of hotels and hospitals. In addition, other supporting businesses like animal breeding and fishery are also developed by pesantren and pesantren network community.

Many achievements and awards have been gained by this pesantren in Bandung Selatan (South Bandung). Satya Lencana Wirakarya 
distinction from the President in 1998; Parama Bhoga Nugraha on the $19^{\text {th }}$ World Food Day in 1999; Kalpataru awards for Living Environment as the environment-friendly without pesticide agribusiness organizer in 2003, Cooperatives and Small-and Medium-Scale Enterprise's service in 2003; $1^{\text {st }}$ Champion of High-Achieving Organization at province level in 2005; Agribusiness Performer in 2006; Bank Danamon Award for notfor-profit category in 2007; and Adhikarya Pangan Nusantara (Archipelago Food Masterpiece) Award from President in 2014.

The name Al-Ittifaq was chosen as the turning point from the history pesantren formerly named Ciburial, small, as best it could, closed to outsiders and applying prohibitive norms. Studying at school, writing Latin letter, permanent house, radio, bathroom inside home, meeting Dutch, and becoming Civil Servant are prohibitions to be avoided. As the grandson of KH Mansur, KH Fuad Afandi has initiated the way out of "pamali (taboo)" trap and such prohibitions since 1974. Those prohibitions seem to be an expression of hostility against colonialist, remaining in its tradition.

The experience with studying in a pesantren (nyantri) in Cicalengka, Banjar of West Java, Lasem of Central Java, and some cities in Sumatera has opened KH Fuad's point of view in developing pesantren, including economic sector. During 10-year period, particularly since 1990, pesantren al-Ittifaq can build internal and external cooperation network. A proverb "utlhubul ilma walau bishshin" is interpreted into a must to search for much information from anywhere and to cooperate with anyone. Being single fighter makes pesantren like bonsai plant. The more the cooperation, the more advance it will be, and vice versa.

The development of agribusiness economic sector is conducted gradually and sustainably by applying economic culturing through integrated education, based on Islam tenet, nationality, and supported 
with local culture. Pesantren applied five principles of business economic development called inpekbi: ilahi negeri, pribadi, ekonomi dan birahi (God, country, personal, economy, and passion/lust). Firstly, Ilahi means that business economy should be dependent fully on Allah SWT, compatible to Allah's game rule. This principle is implemented in the tenet of shalat berjamaah (prayer in congregation) at the beginning time. As soon as adzan echoes, any activity should be abandoned.

Secondly, country principle means that business economic development may not ignore government regulations. Economic development is the implementation of citizen's service to the state and homeland. Thirdly, personal principle emphasizes on a must to prepare superior, highly-competitive human resource (HR) having noble character. Discipline, work ethos, and morality integrity are points emphasized on highly in daily activities in the pesantren. Fourthly, economic principle means that all economic activities are a part inseparable from worship obligation that should be profitable. If some loss occurs, it is interpreted into the presence of something wrong needing way out and solution immediately. The word 'profitable' here is interpreted not only for personal interest but also for fellow human beings. The profit gained is not free of many parties' help and cooperation. Therefore, all efforts should build on kinship and ukhuwah principle. Ukhuwah is interpreted not only as fraternity based on blood relation, but inner bond and commitment as members of religious community, as citizens, particularly as the members of pesantren Al-Ittifaq network.

In addition to the principles above, the fifth principle sounding to be "strange" is lust (passion). In this pesantren, the lust principle is managed and developed to support the business entity development and to reinforce cooperation particularly between fellow pesantren economic communities. This principle is implemented to mating and alumni 
development as the agent of pesantren, in Islamic education mission and economic development all at once.

Santris who have entered marriage age will be mated with son or daughter of village leader, as village is the target of dakwah (proselytizing) to Pesantren. Or, otherwise, the son of society leader will be mated with the female santri. On every Maulud Nabi celebration, pesantren holds mass marriage, i.e. marrying a few couples resulting from the mating. Every new couple should be given dwelling, capital, and should be placed in the targeted area. This pattern is called seeding the alumni of pesantren, positioned to be the continuing the mission of pesantren and supporting the economic community of pesantren.

In addition to inpekbi tenet, $5 \mathrm{M}$-leadership doctrine and Sundanese culture local wisdom are also applied. Leadership doctrine consists of meyakinkan, menggalang atau memobilisasi, menggerakkan, memantau dan melindungi mengayomi (convincing, raising or mobilizing, driving, monitoring and protecting or sheltering). Meanwhile supporting local wisdom includes optimization and implementation of proverbs in daily life like silih asih silih asuh and silih asah (loving each other, taking care of each other, and promoting each other for mutual advance). Another proverb implemented is Ulah unggut kalinduan ulah gedag kaanginan (may not be tempted and changed easily, just like being affected with wind blow). Still another proverb is Sing katepi ku ati sing kahontal ku akal (should be reachable to heart and understandable to mind).

Silih asih means loving each other, for example, by sharing knowledge and experience. Silih asah means sharing knowledge and technology for the advance, generating progressive ethos to the growth of independence. Silih asuh requires an attitude of protecting each other, building each other, and helping the poor one. Proverb ulah unggut means a must to have consistency and consequence to truth. Meanwhile, proverb 
sing katepi means that every attitude and action should be synchronous with heart, conscience, and mind. Before taking action, please determine the heart and mind first precisely.

Pesantren's tenet doctrine and local wisdom have reinforced collective consciousness in economic development, particularly realizing the cohesiveness of pesantren community as a solid pesantren economic community. "Paheuyeuk-heuyeuk" (Supporting and helping each other) in implementing two khidmats (two services): khidmatun lil ummat wa khidmatun lil ma'had (service to religious community members and service to pesantren) in order to improve the economy and welfare of fellow human beings. Supporting and propping each other and being market oriented are other principles to be implemented. It really becomes a loss when a product is not acceptable to market. Collaboration between Islam tenet and local wisdom powers has made the realization of pesantren economic community network running more smoothly. The attempts of going forward collectively build on high trust in the pesantren's leader and fellow community members.

Agribusiness-based economic development in Al-Ittifaq is implemented using pesantren network model consisting of pesantren business entities: cooperatives of pondok pesantren (kopontren) now named Al-Ittifaq corporation, with motto: integrity, honest and professional. AlIttifaq corporation manages all resources in order to reinforce and to expand the pesantren business entities reflecting on sustainable integrity and productivity. Organizational management, human resource, operational system, and value order is implemented in a pesantren's leadership. With pesantren economic community network's management and support, market demand can always be met. Al-Ittifaq corporation consists of farmer groups, LM3, P4S, DKM, alumni, and cooperation partners. The figure above represents the relational pattern positioning pesantren to be the primary key function. 


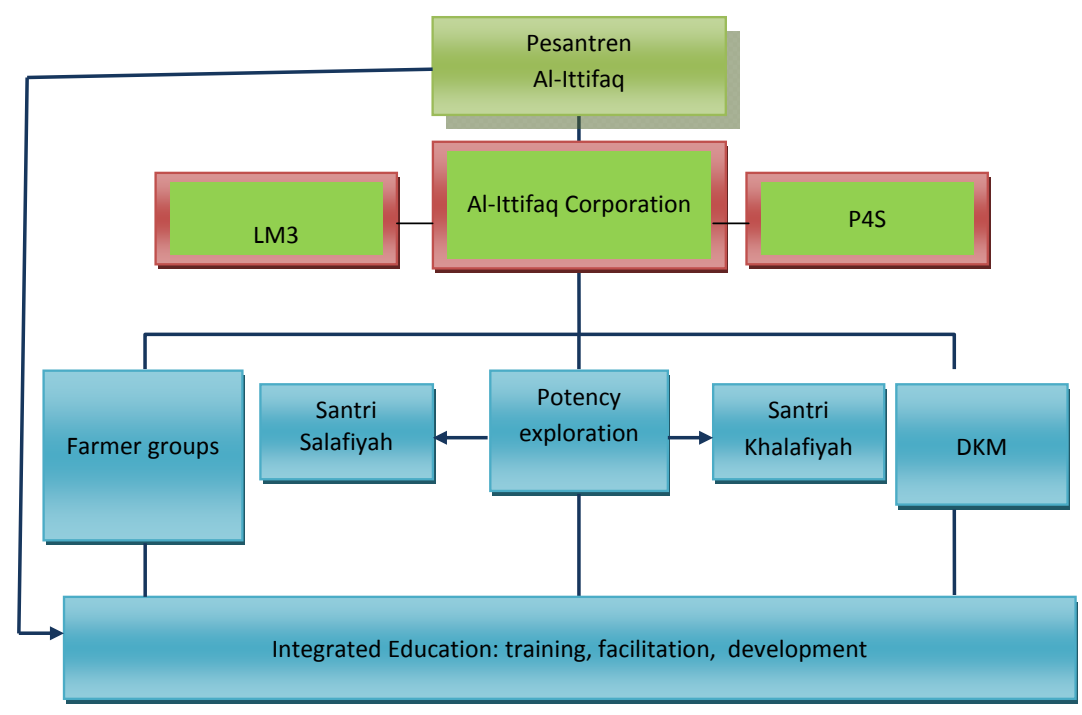

Figure 1.

Relational Pattern and Structure

The relational pattern and structure consist of LM3 (CommunityBased Independent Institution), farmer group, P4S (Self-Help Farming and Rural Training Center Pattern), DKM, and santri. LM3 is an Agricultural Department's program aiming to promote community economy. P4S was established by Al Ittifaq and community based on license gotten from Agricultural training House of Human Resource Development and Education Agency of Ministry of Agriculture in Lembang. DKM is mosque welfare council established by community under pesantren's building. They develop community economy in agribusiness sector. They cooperate to develop community economy in agribusiness sector. Agribusiness development is conducted in pesantren-owned and farmer groups-owned lands. Pesantren and farmer groups become supplier of vegetables and fruits with standard quality-A (supermarket-quality) to meet 
the modern market's demand through Al-Ittifaq Corporation. Pesantren is the protector or guardian of all community members in pesantren network.

The management of pesantren- and farmer groups-owned farming land is divided into 6 foremanship systems. Each 1-4 Ha wide overseeing system is headed by a foreman, with $12-80$ members. The distribution of pesantren network farmer group, foreman, land width, and coordinator is presented in the table below.

Table 1

Farmer Group, Total, Land and Coordinator

\begin{tabular}{|c|l|c|l|l|}
\hline No & Farmer Group & Foreman & \multicolumn{1}{|c|}{ Land Width } & \multicolumn{1}{|c|}{ Coordinator } \\
\hline 1 & Alif & 31 & 14 ha & KH. Apep Syarifudin \\
\hline 2 & Jampang Endah & 35 & 22 ha & H. Muhaimin \\
\hline 3 & Tunggal Endah & 32 & 20 ha & H. Asep \\
\hline 4 & H M S & 29 & 20 ha & H. Utang \\
\hline 5 & Mekar Tani & 27 & 8 ha & Wawan \\
\hline 6 & Tani Ulin & 23 & 6 ha & Hj. Netti \\
\hline & Total & 177 & 90 ha & \\
\hline
\end{tabular}

Farmer groups acquire training and building from Al-Ittifaq Corporation involving production quality, individual capacity improvement, and product quantity. Their business becomes more organized thereby strengthening bargaining power, particularly in the term of pricing. They are trained and get consultation concerning farming, technology, seedling, cultivation, fertilizer, sorting, grading, wrapping, labeling etc. The demand of modern market, hypermarket, supermarket, hotel, restaurant, and hospital is supplied by the productivity of pesantren economic community network breeding.

Economic community network agribusiness breeds about 25 types of vegetables, from seedling, cultivation, delivery, marketing, to organic fertilizer and other supporting business such as animal and fish breeding 
(Syahid, 2012). Even some farmer groups have bred vegetable commodity types usually imported for modern market since 2008. Those vegetables are Dutch eggplant, kyuri or Japanese cucumber, daikon or radish, horenzo, a kind of spinach, and etc) (Irawan, 2019). Pesantren Al-Ittifaq has had a factory of basic material for ready-to-use (food, horticulture) plant fertilizer compost with MFA (Mikroorganisme Fermentasi Alami or Natural Fermentation Microorganism) brand located in Garut. AlIttifaq corporation has monthly sale volume of IDR 300,000,000.00$440,000,000.00$ or IDR 3.6 B - 5.4 B. Even on certain months it reaches IDR 450,000,000.00-520,000,000 per month (Neneng, 2016). In the period of a week before Ramadhan to a week after Eid al-Fitr, the sale volume can reach three folds more than the normal one (Irawan, 2019). This sale volume still excludes the on resulting by farmer groups that also supply commodities to traditional markets and export strawberry to Middle East.

\section{Global Market and Community Economic Development}

Globalization has developed almost-disappearing geographic partitions. World becomes more opened and flatter. Transportation and communication technology advance have made the world a transparent, borderless and compressed space. Interaction is not conducted based on tight distribution into international, regional, national, province, regency, and even village. World has been a common house, in which mobility sits adjacently to connectivity making the life like storing time in its right pocket and distance in its left pocket. Deterioration is interpreted to be current, traffic, interaction, and material and physical movement supporting economic production and social reproduction conducted in a space (Refi and Ziyad, 2014: 31-36). 
In such condition, a contestation has occurred between market capitalism represented by America and Europe and state capitalism represented by China in 2000s era. Such contestation indicates the weakening market capitalism as characterized with the attenuation of stability and the global economic recession due to the fading trust in overseeing system organized by the state. At the same time, free trade does not have strong foundation for the perfect competition. Because of that wave, China has benefited very much from the shift of world's economic gravitation center from the West to the East. It is predicted that new economic middle-class will arise and develop in China, India, including Indonesia. Asian states strengthen the trading relation between fellow Asian states by positioning China to be the node of regional trade (Bremer, 2011: 204-8).

South East Asian mercantilism tradition, to Bremer (2011: 2445), has been destroyed during $17^{\text {th }}-18^{\text {th }}$ centuries under the combined effect of European colonialism and absolute ruler. Since then, Europeans control the strong economic peaks and excludes only Chinese people who dominate their medium sectors. Hal Hill notes that Indonesian modern economy is dominated more by a number of big conglomerates with broad activity in industry and trade. Such domination is inseparable from personal bond of conglomerates to New Order president and seniors. Structural reform in 1980s seemed to increase the domination of massive multisector companies only over the market and to renew their worry that the more liberal the Indonesian economy, the lower is the role of Muslim and native people.

The competitive advantage of Chinese economy in East Asia lies on its application of industrial sector grouping or clustering, involving local and national governments. Japan groups high-technology industrial areas into robot, space, and nano-technology. Korea wrestles with information 
technology, shipping, and environment. China builds automobile, petrochemical, machinery, electronic, steel, fashion, textile, and food clusters based on knowledge (Wishanti, 2014).

The problems are "will the effect of market capitalism in Indonesia be replaced with ala-China state capitalism? Are state capitalism model more profitable in our homeland? In developing countries, including Indonesia, capitalism has developed along with diverse social structures and moral traditions. Similarly, it represents typical complexity in Asia. The strength of network like quanxi to capital accumulation in Taiwan, or the communist' support to private company in Vietnam, has colored capitalism in Asia. As such, capitalism has worked through the articulation of political community, organization, and local culture. As soon as the reinforcement of local cultural value occurs, company (capitalism) will transfer resource and relation to its locality to the new objective directions that are more profitable. It can be accomplished by adjusting or even erasing previous form (shape) or pattern. The existence of social structure and cultural value sentiments is utilized to be the new breath to capitalism sustainability (Hefner, 2013: 236-7).

The accommodation of economic morality by capitalism essentially oppresses locality values. In such accommodation, local tradition should be subjected to economic demand and leave certain social value with the claim that it has deviated from the new world's demand. As such, Capitalism reveals friendly side on the one hand, but displays its original face on the other hand, rather than providing justice and welfare. Although the community's attitude has changed and accepted market capitalism, Hefner believes that majority Muslims cannot enjoy the distribution of Indonesian development cake.

The penetration of market capitalism leads the developing states like Indonesia to face two conditions. Firstly, the domination of opened 
retail market or free service market by Multi National Corporation (MNC) monster recently conducting oligopolistic, competition among the few, State is over and market is coming. Secondly, the requirement of the presence of state amid its strong urges to reduce intervention in free trade system. It is in this context that the Law Number 5 of 1999 about the Prohibition of Monopoly Practice and Business competition is present, as embodied into the Business Competition Supervising Commission (KPPU). The state may not leave the business performers' helplessness in facing oligopolistic economic actors (Kaylani, 2011: viii-x).

In reality, both market capitalism and state capitalism equally have positive and negative sides. Viewed from global economic side, the two capitalisms give an opportunity to the operation of post-colonialism imperial power demonstration. It is the demonstration of imperial power synchronous with the world's economic constellation when territorial expansion begins to be needed. Considering this, a variety of expansions for the sake of dominating emerging market is conducted to compensate the limited productivity in its country. Emerging market in the third world hemisphere is dominated on behalf of development policy or new world order that is essentially neoliberal. The liberal economic theory believes that economic welfare can be maximized when the two production factors, i.e. capital and labor, can move from one place to another (Refi and Ziyad, 2014)

At rural level, globalization can be seen from the past context, as the embryo of colonialism. It is important to see the context of underdevelopment occurring in rural areas during colonialism era thoroughly. Village is a micro economic entity, while colonial state is macro capitalism entity. The two is in synergy in parasitism symbiosis relation. Colonial state is present as parasite to involute rural economic order (Raharjo Jati, 2014). Globalization is interpreted into an interdependence 
relation between world states in social-political and economic areas, enabling a variety of cooperation to run smoothly. However, generally what has occurred is not interdependency but dependence on capital power so that cooperation results in exploitation and asymmetry, and is far from justice.

The entry of global actors through cooperation and help (aid) to villages welcomed by villagers has disguised the motive behind cooperation. Consequently, its effect predisposes cosmopolitan villages to be worse. Superpower states like America, Europe, and Japan keep trying to master Indonesian resource. Even new world powers like China, India, and Korea also compete for the village. In such situation, there is no more potent exit strategy but the fully independence attitude just like the vision of state's founders. The word "being fully independent" does not mean selfish, exclusiveness, and anti-cooperation. However, it should be realized that there is always completion in each of cooperation. Thus, fully independence should be manifested into the bravery to oppose neoimperialism domination.

In many cases, rural areas, particularly in its locality character has strategic potency as the last fortress to ward off the penetration of globalization power. Local wisdom is the prescription healing the adverse effect of globalization on social and cultural aspect of community (Refi and Ziyad, 2014). The pesantrens generally existing in rural areas have local wisdom power, originating from the implementation of Islam and tradition, and potentially becoming the fortress to ward off global penetration.

Local wisdom in all aspects of community life have strategic potency to be social capital composing the fully independence; independence even can oppose neo-imperialism domination. Even such social capital has strategic potency to be capital asset. It is this point that will be elaborated 
from the role of economic pesantren. Economic pesantren is the one with independent economic business that has successfully driven the community economy surrounding. It is this community that is called pesantren economic community.

Community economic development (CED) is a community empowerment pattern focusing on a community. CED, according to H.W. Armstrong, P. Wells and A.M. Wood, should have four characteristics. Firstly, it should have various objectives for the sake of improving economic life. Secondly, it should lead to the achievement of various benefits to the members of community. Thirdly, the benefit achieved should be stable in long term. Fourthly, the consequence is a broad economic network leading to the improved welfare and social justice (2000). At medium-scale, the achievement of community economic productivity can contribute significantly to the nation's economy and can oppose the penetration of Market Capitalism. The sustainably successful community economy can contribute positively to aggregate national economy and its independence gradually but certainly.

\section{Pesantren Economic Community}

Pesantren economic community is a community group with social and spiritual relation to pesantren, in a network bond. Pesantren Al-Ittifaq develops agribusiness economy through developing santri community and society with economic education and culturing. In its process, having passed through up and down process, the agribusiness economic development achieves the success. The success gain builds on the application of planting pattern system, production pattern, post-production product processing, marketing pattern, and economic community network power. First, pesantren convinces the community by giving successful role modeling, to be transferred to the community gradually and sustainably later. This 
process is confirmed with the pesantren alumni planting pattern or the alumni seeding system in targeted villages (kampongs).

The pesantren-community network power in pesantren economic community becomes a golden bridge to the successful economic business of pesantren under Al Ittifaq Corporation. This pesantren economic community network not only supports the pesantren sustainability but can also strengthen the pesantren's role and function in improving the society welfare. Through that role and function, pesantren Al-Ittifaq has successfully expanded its function from social-education to social, education, and economic one. Network power supported with human resource capability has automatically improved its competiveness.

A success is inseparable from a continuous hard-working process. In institutional context, the inadequate effort in congregation (berjamaah) seems to be the primary cause of failure. Pesantrens that have had superior internal power in education and its network can be evidently successful in developing economic sector. Pesantrens Maslakul Huda Pati, Sunan Drajat Lamongan, Gontor Ponorogo, Sidogiri Pasuruan, Al-Amin Sumenep, Al-Amin Kawalu Tasikmalaya, Darunnajah Arrisalah Ciamis, Al-Amin Kawalu, Al-Ashriyah Nurul Iman Parung, and Qomarul Huda Lombok are some of pesantrens with superiority in productive economic sector (Fauroni, 2014).

Pesantren Al-Ittifaq is highly aware of its strategic position of partnership cooperation and network development either inside community or outside. Without partnership network, the expansion of pesantren's function in community economic empowerment will be achieved difficultly. Al-Ittifaq is defined as cooperation for the progress or advance. Farmer group network is established gradually from the closest (local) villagers, then shifting to the villagers in adjacent village and so forth with pesantren being the center point. First, 2-3 farmer groups are 
established, consisting of santri, alumni, and village elder leader aiming to conduct planting pattern system in agribusiness in order to prevent product flood from occurring. The development of network is synergized with economic cultural education in pesantren and by building prospect alumni cadre by means of teaching apprenticeship in targeted villages to implement the mission of pesantren. The placement of alumni in a village through mating is intended to develop pesantren education and then to promote it to agribusiness development and product marketing, as the agent of Al Ittifaq Corporation as its plasma core company.

Partnership pattern of Al-Ittifaq economic community can be represented as follows:

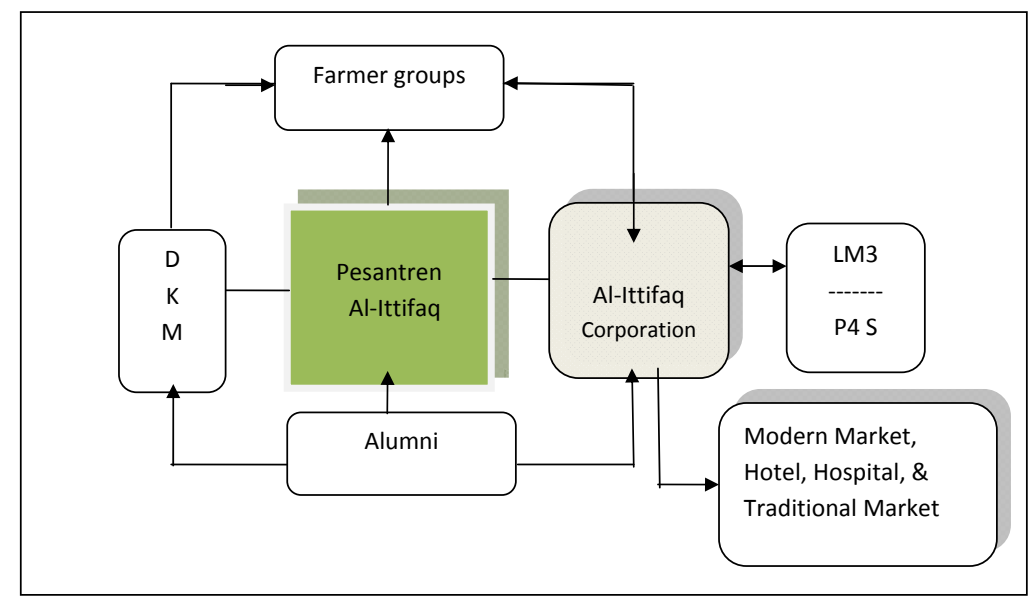

Figure 2

Pesantren Economic Community Network

In its early development period, agribusiness economic entity and partnership with outsiders were under direct control of KH. Fuad Affandi, particularly during 1999-2000. Gradually, its management was decentralized through collective leadership in the management of pondok 
pesantren's cooperative (kopontren) and LM3 now becoming Al-Ittifaq Corporation. This decentralization has begun since 2000s. Departing from one or two farmer groups, several alumni and Masjid Welfare Council (DKM), KH Fuad's relatives and best friends, this cooperative was developed gradually.

Alumni seeding pattern, mating, and DKM support the reinforcement, the expansion, and the increase of farmer group number. The farmer groups are currently managed by the second generation, son or son in law of the first-generation managers. In 2012, there were 36 DKMs (Dadan Muttaqin, 2012), and it increased to 38 DKMs in 2016. There were 380 active network members in addition to other hundreds of members affiliated with the larger farmer groups. Other two farmer groups were established in 2014, so that there is a total of 9 farmer groups in 2019. Pesantren Al-Ittifaq's economic community network has a total of 1075 members per 2018.

The first-generation farmer group includes farmers groups HMS (Hasil Melak Sayur or Vegetable Planting Result), CV. One or Karisma, Al-Ittifaq, Gamlok, and Mekar Mukti (Ahmad Syahid, 2012). Every farmer groups have 2-3 built farmer groups: Kembar Putera, Tani Ulin, Jampang Endah, Tunggul Endah, Cikoneng, Kiara, and etc. The secondgeneration farmer group leaders are, among others, $\mathrm{H}$. Hendi Saputra, $\mathrm{Hj}$. Netty Sa'adah, H. Ayi Sutisna, H. Didin Karisma, H. Asep Tatang, ustadz Aceng, and etc. The development of new farmer groups is conducted continuously to keep them developing.

The responsibility of built farmer groups is undertaken by the main farmer group. All farmer groups are under the coordination of 38 Masjid Welfare Councils distributed in all areas of Rancabali sub district. Two farmer groups were established in Cianjur Selatan (South Cianjur) regency area in 2014. The strong bond between farmer groups and Al-Ittifaq does 
not limit its product selling. They can market their harvesting product independently. In addition to be an agent of Al-Ittifaq corporation, they can supply vegetables to main markets in Jakarta, Bandung, and traditional market. Even some of them market their product to outside Java.

Al-Ittifaq corporation can be illustrated as play maker in soccer (football game), balancer, feeder, attack (marketing) promoter, goal maker (MOU of partnership with business entity), and the users of community members' business product. Al-Ittifaq Corporation reinforces the marketing function; maintains partnership, and expands new market. AlIttifaq Corporation has established long term work contract with several partner companies: Hero hypermarket, and supermarket (Jakarta), Merlin, Yogya Department Store, Ramayana, Matahari, restaurants, hotels and a number of hospitals in Bandung.

The development of pesantren economic community network, according to K.H. Fuad Affandi (2012), is the application of do'a (prayer): Allâhumma innî a'ûdzubika min ilmin lâ yanfa'

"Having property will not be eternal, but having science (knowledge) will be eternal. Through alumni seeding, Alhamdulillah the alumni of pesantren can utilize their knowledge and empower the community's economy and to have sufficient property. Pesantren's duty is not to make the community like Arab but to make it Islam community (Muslim). This pattern imitates Sunan Kalijaga's proselytizing model, not making Javanese an Arab, but making him/her Muslim”.

The development of economic business may not override the main mission of pesantren: education and community empowerment. Some of farmer group names are taken from the name of madrasah diniyah, with masjid and DKM being its pivot. Economic development is always supported and reinforced by the implementation of Islam tenet values including tasawuf and sundanese value teaching. Tasawuf is aimed not to 
avoid the property ownership, but to control it for better usefulness and for family and neighbor's welfare. KH. Fuad said that bakal cilaka dua belas (it will be lost and going bankrupted as much as possible), those who are happy with others' misery. The success of business economic lies not on individual smartness but on the result of cooperation and help from many parties.

The reinforcement and facilitation of pesantren economic community members are also accomplished by positioning the fellow members to be sibling. It is also confirmed with weekly, monthly, and annually patterned silaturahmi. In the moments of Maulid Nabi and Isra' Miraj Islam Holy Day celebration, silaturahmi is held for 38 full days, in which every DKM holds silaturahmi and Quran study (pengajian) ended with the peak celebration in pesantren environment. The peak of Maulid Nabi celebration was signed with the organization of mass marriage, while that of Isra' Mi'raj with mass circumcision. The celebration of halal bihalal (forgiving each other) is filled with pesantren alumni meeting and Annual Member Meeting of Kopontren.

With all facilitation patterns, santri, alumni, farmer group, DKM, and community have been able to improve social capital of ukhuwah into capital asset for the sake of economic empowerment and community welfare improvement. Fraternity should be prioritized and maintained. When oversight, dispute, competition for customer, and payment delay occur, they will be positioned to be the consequence of business economy that will always be elaborated and resolved in discussion manner, so that they will be solved well. From the area coverage, the development of community network starts with the villages adjacent to pesantren complex, and then expands to the areas beyond the village, and even sub district and regency. Or it prioritizes the villages far from religion tent and inhibiting the mission of pesantren. It is intended to make the pesantren's program and the community empowerment program to run smoothly. 
Two farmer groups are located in Cianjur Regency area, exactly in Cikuda and Citarup. These two farmer groups have been established formally since 2013-2014. The two farmer groups are developed from the expansion of madrasah diniyah function managed by pesantren alumni. Both of them specifically become the pivot of low-land commodity agribusiness developers such as ginger, turmeric, galingale, and etc. The map of pesantren economic community network distribution by its geographic location aspect is displayed below.

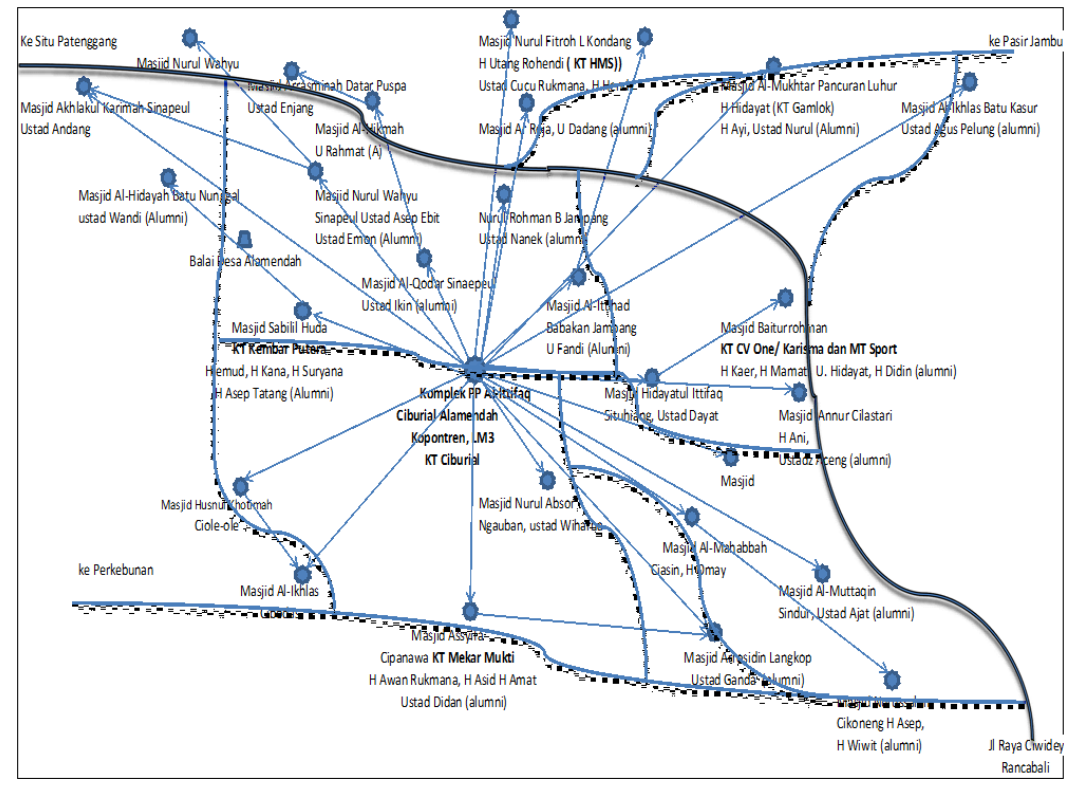

Figure 3

Map of Pesantren Economic Community Network Distribution

\section{Cooperation, Competitiveness, and Welfare Improvement}

Global economic era gives many economic performers more opportunity of competing, not only between local and national economic actors but also economic actors coming many countries. Competition 
automatically becomes higher. Pesantren Al-Ittifaq economic community understands and positions competitions in global era as the logical consequence of as sunnatullah of business economy. The competition is faced with a consciousness of an imperative to compete and to prioritize superiority and achievement. Only those with superiority will win the competition. In pesantren economic community, the development of consciousness of competition and competitiveness imperative is inculcated earlier to santri, alumni, DKM, farmer group, community, through many moments. Without achievement or superiority, it will be automatically eliminated from the competition world. Similarly, the expansion of cooperation by Al-Ittifaq Corporation will lead consequently to the improved competitiveness and superiority.

The competitiveness of pesantren economic community is affected by internal and external factors. Internal factor involves management, technology, planning, and long-term investment knowledge and ability. External factor includes price, production factor, nature, supporting infrastructure, marketing media, non-production cost, environment, and business world climate. If it can deal with internal and external factors well by prioritizing achievement and superiority, it will surely win the competition. Gaining the competitiveness is more difficult than gaining survival. Gaining success is difficult, but maintaining success is more difficult. The existence of economic community in Al-Ittifaq Corporation can deal with many difficulties.

The habituation of competitiveness consciousness in order to win the competition in global economic era has been developed earlier through inculcating tenets and values in pesantren education process. The application of planting pattern SOP will result in super-quality commodity; sorting, grading, wrapping and labeling SOP is enacted and perfected gradually in line with the development of cultivation and marketing technology. It also 
emphasizes on the imperative to have $3 \mathrm{~K}$ culture: quality, quantity, and continuity (kualitas, kuantitas, dan kontinuitas). H Ayi Sutisna, H Hendi Saputra, H Didin Karisma, and H. Awan Rukmawan (2012) suggested a principle to win the competition that is always taught KH. Fuad and becomes guidance: "Papaliwat nyimpang, pasered-sered geser, kapiheulaan lumpat." (If you meet others on the street, it will be better to move to side for a moment. If it is crowded, it will be better to move slightly to another place [as everyone has equal right]. Don't be angry when someone overtakes you, but you should run to catch up him/her and show your high performance).

The tenet is elaborated into business economic behavior and even daily activities. If someone defeats us in the term of product quality and price, we should catch up him/her by improving performance (achievement) in the term of quality and price, in order to compensate and to surpass him/her. We should not compensate him/her emotionally by breaking the ethics or law. In business economic practice, it is not religion proposition but hard work and vigorous effort that should be increased. Do more, speak less. Improve work ethos rather than output ethos. Allah appreciates his creatures' working process and effort more.

A variety of agribusiness commodity orders from several modern markets is sent to kopontren via facsimile, and socialized to the members of community to be fulfilled manually. Along with technology development in 2013, pesantren Al-Ittifaq builds internet network to facilitate reservation and socialization reinforced by WhatsApp group member community. The fulfillment of any commodity orders is socialized in real time through WhatsApp group. In this group many findings of cultivation technology, pest management, product marketing, and etc are socialized as well. Pesantren Al Ittifaq has been elected to be the work partner of JICA of Japan in developing cultivation technology and halal food in 2016. The 
cooperation with Japan has been conducted in the attempt of preparing for the 2020 Olympic, and of developing the cities with halal food facilities, completed with its rightfulness guarantee, Japan Islamic Trust. Many halal food restaurants and even sharia hotels have been established in many cities in Japan. Japan has provided "Halal Gourmet Japan" or Halal Navi - Restaurant Mosque" gadget application in Google Play or App Store as well.

The pesantren has also cooperated with Netherlands in 2018 in developing cultivation technology to provide a variety of agricultural commodities in Europe. Two members of pesantren community went to Netherland for two weeks on May 2019 to follow-up the cooperation. In the beginning of cultivation development, exactly in 2002, KH Fuad Affandi learned cultivation technology and harvest product processing technology in Netherland. Since 2019, pesantren Al Ittifaq has cultivated hard fruits on a 2-ha wide land in Cijeruk, Bogor Regency. Through its cooperation and expansion, the pesantren economic community gets many advantages: firstly, the improved cultivation management impacting on the improved productivity of cultivation product commodity; secondly, the guaranteed marketing channel for many commodities through AlIttifaq Corporation as the nuclear leading to sustainability and continuous income; thirdly, the improved competitiveness of community member and the elimination of brokers who love to play with price; and fourthly, the improve welfare and social justice for the fellow members.

Al Ittifaq Corporation does not limit and even give its community members a discretion to establish partnership with anyone. Thus, several communities have established cooperation with many parties, at local, national, and international levels. Through this position, there has been healthy competition between community members and farmer groups in which they compete for gaining success. The case of competing for target 
market and customer is indeed inevitable, but with the consciousness of competitiveness and strong fraternity, the dispute can be resolved in discussion manner.

The improved welfare is basically a logical consequence of a business' success. Similarly, a community's welfare is the consequence of its successful economic businesses. In economic measure, welfare level can be seen from such indicators as high and stable income, residence, two-wheel and four-wheel vehicles etc. Those indicators facilitate the determination of welfare or pre-welfare criteria. Nevertheless, the true welfare is material and non-material aspects all at once, for example, happiness. Considering the result of observation, material aspects have been surpassed by the members of pesantren Al-Ittifaq community.

It is also confirmed by H Cucu (47 years), Asep Daud, (35 years), Yudi (24 years) stating that their income resulting from their agribusiness becomes more stable after they join the pesantren economic community network. Before the presence of Al-Ittifaq Corporation, the three of them sell vegetable harvesting product dependent on the middleman, so that consequently they should receive any price specified by the middleman, or they should sell it directly to traditional market with fluctuating price and substantial transportation cost.

With pesantren economic community, the members of community can get many advantages and benefits: the certainty of vegetable plant types needed by market, the availability of seed and fertilizer, sharing cultivation technology, and certainty of harvesting product purchasing by Al-Ittifaq corporation if it meets the specified standard. Similarly, they can get loan, save money, and follow arisan, through Al-Ittifaq; thereby they can program better their need for child tuition, saving, arisan, capital loan, and other needs like education cost, house renovation, house construction, circumcision, walimatul ursy, and buying both two-wheel and four-wheel vehicles. 
The presence of pesantren economic community is considered as capable of fulfilling material and spiritual needs, life happiness. The close fraternity relation facilitates problem solving among the members of community. The problems of worship and religiosity can be asked directly to kiai or ustadz in DKM or during pengajian. Agribusiness, management, development, and marketing problems can be solved through farmer groups and Al-Ittifaq Corporation. The improved welfare can be seen from the fulfilled food, clothing, and shelter needs. Majority community members' houses have been constructed permanently. Even some of them are two-floor buildings costing billion rupiah. It can also be seen from the average four-wheel and two-wheel vehicles fulfilling pesantren's yard and neighborhood, during attending the Islam Holy Day celebration events (PHBI).

The successful construction of sturdy and grandiose mosques (masjids) in every village as a result of community members' donation proves the high social cohesiveness power followed with financial ability. Mosques in every village are constructed with about IDR 500,000,000.001,200,000,000.00-fund. Similarly, the ability of community members to undertake hajj and umrah worship improves. On average, 30-40 members of community undertake umrah, and community members including pesantren alumni have undertaken hajj worship in their 30-year age. The indicator of income aspect can be seen from the table showing the mean monthly income of community members below. 
Table 2

Mean Income of Community Members

\begin{tabular}{|c|l|l|l|}
\hline Group & $\begin{array}{c}\text { Land Width } \\
\text { (Tumbak) }\end{array}$ & Land Width (M2) & Mean Monthly Income \\
\hline I & $200-350$ & $2800-4900$ & $6,000,000-7,500,000$ \\
\hline II & $400-600$ & $5600-8400$ & $8,000,000-10,000,000$ \\
\hline III & $650-750$ & $9100-10500$ & $11,000,000-13,000,000$ \\
\hline IV & $800-1000$ & $11200-14000$ & $14,000,000-19,000,000$ \\
\hline V & 1000 & $>14000$ & $>21,000,000$ \\
\hline
\end{tabular}

As the main company, Al-Ittifaq Corporation often conducts production processing and marketing, and uses and develops the income resulting from the community members' business efficiently. Production process is the process of planting, breeding, harvesting, warehousing, and marketing. While the use and utilization of community business' product efficiently includes the management of cooperative members' asset (postsale) to improve their welfare. The use and utilization of product efficiently is to manage Allah's gift to meet the productive financial needs.

Thus, the opposition against the penetration of market capitalism conducted by Pesantren Al-Ittifaq economic community with cooperating strategy leads to the improved competitiveness consequently. Cooperating with semi-modern market business entity is different from cooperating with hypermarket, hospital, and hotel. So is cooperating with foreign companies and internal cooperation. Each of cooperation has different specific consequence. The experience with experience impacts on the improved competitiveness and encourages the improved cooperation with large business entity at large scale as well. 
As such, the presence of pesantren economic community has made the social capital owned transforming into capital asset. The Islam religion tenets about an imperative to be powerful economically and to use the entrusted properties efficiently and the local wisdom have made the capital asset of pesantren economic community sturdier. The sturdy capital asset owned makes the community and its members alerted and independent. They will have strong bargaining position, thereby can anticipate any loss occurring. Through high capital asset and competitiveness, cooperating agreement will be achieved when it has been considered as benefiting the parties mutually.

\section{Conclusion}

Pesantren can successfully build strong economic community as the implementation of integrated education and economic culturing involving value inculcation, role modeling, facilitation, empowerment, and protection. The pesantren economic community has strategic potency, in the presence of social capital of high trust in the pesantren. Pesantren is required to prove its economic business' success gradually or simultaneously, to make the community trusting it more. High consciousness of its cooperating strategy in competition era automatically improves the competitiveness. The capital asset power of economic community becomes strategic power to expand cooperation, particularly with outsiders. Cooperation with anyone even those with different religion will improve competitiveness. Cooperation in strong competitiveness position consequently impacts on strong independence and bargaining position so that cooperation will be functional and mutually benefiting.

Pesantren Al-Ittifaq has resulted in social entrepreneur community transformed into the strong capital asset of economic community. In social entrepreneur, the powers of shared value, trust, and cooperation culture 
are most important form that can strengthen economic cooperation. Similarly, mutual trust, mutual respect, mutual benefit, social organization, and leadership in strong community network will impact directly on cooperation and improved competitiveness, independence, and welfare. Pesantren Al-Ittifaq economic community can achieve the improved economy collectively, get much benefit, and achieve stable income and welfare, and social justice. The community's capital asset coming from social capital can evidently oppose the penetration of market capitalism effectively.

\section{Acknowledgment}

The author warm thanks to Direktorat Pendidikan Tinggi Keagamaan Islam, Direktorat Jenderal Pendidikan Islam Kementerian Agama Republik Indonesia who had provided a doctoral scholarship for completing this research. 


\section{References}

Bawono, Anton. (2018). Creative Economic Development of Pesantren. Shirkah Journal of Economics and Business, 3: 1, January-April 2018, pp. $26-43$

Bremer, Ian. (2011). Akhir Pasar Bebas The End of The Free Market, Bangkitnya Kapilalisme Negara dan Ancaman Jangka Panjang Bagi Perekonomian Dunia. Jakarta: Gramedia.

Fauroni, R Lukman. (2014). Model Bisnis ala Pesantren, Filsafat Ukhuwah Menembus Hypermarket Memberdayakan Ekonomi Umat. Yogyakarta: Kaukaba-Bisyar Consulting

Fauroni, R Lukman dan Mujahid Quraisy. (2018). Agilitas Ekonomi Pesantren, laporan penelitian Diktis Kementerian Agama.

Hefner, Robert W. (2013). Islam Pasar Keadilan Artikulasi Lokal, Kapitalisme dan Demokrasi. Yogyakarta: LKiS.

Jati, Wasisto Raharjo (2014). Globalisasi Dan Kemiskinan Desa: Analisa Struktur Ekonomi Politik Pedesaan Globalization \& Village Poverty: An Analysis of Economic-Politics in Rural Area, Jurnal Penelitian Politik, 11: 2 Desember.

Kaylani, Ahmad. (2014). Catatan Editor buku, Negara Dan Pasar Dalam Bingkai Kebijakan Persaingan, Jakarta: Komisi Pengawas Persaingan Usaha.

Panadji, Tri. (2013) "Penguatan Modal Sosial untuk Pemberdayaan Masyarakat Pedesaan dalam Pengelolaan Agroekosistem Lahan Kering”, wwwpse.deptan.go.id. retrieved from 26 April 2019.

Refi, Wahyuni dan Ziyad Falahi. (2014). Desa Cossmopolitan Globalisasi dan Masa Depan Kekayaan Alam Indonesia. Jakarta: Change Publication.

Sastosa, Setyanto P. (2012). "Peran Social Entrepreneurship dalam Pembangunan", "Membangun Sinergisitas Bangsa Menuju Indonesia Yang Inovatif, Inventif dan Kompetitif", IESP FE-Universitas 
Brawijaya, Malang, 14 Mei 2007, diunduh dari www.koom.pacific. net.id. 26 April 2019.

Stake, RE. (1995). The Art of Case Study Research, California: Sage Publication.

Wells, H.W. Armstrong, P. and A.M. Wood, The Evaluation of Community Economic Development Initiatives, http://citeseerx.ist.psu.edu.

Widodo, Slamet. (2016). "Model Pemberdayaan Pondok Pesantren dalam Pengembangan Budaya Kewirausahaan", Prosiding Seminar Nasional Penyuluhan Pembangunan Nasional 2016, "Pengembangan Kompetensi Fasilitator dan Kelembagaan Pemberdayaan Masyarakat di Era MEA" Hotel Lor In Solo 30 November 2016.

Wshanti, Dewa Ayu Putu Eva. (2014). Kebangkitan China dalam Kerjasama Ekonomi Internasional di Kawasan Asia Timur, Jurnal Transformasi Global 1 (1), 1-21.

\section{Informants}

KH Fuad Affandi, 65 years

$\mathrm{H}$ Irawan, 35 years

H Awan Rukmana, 52 years

H Dadan Muttaqin, 38 years

H Ahmad Syahid 42 years

H Ayi Sutisna, 35 years

H Hendi Saputra, 35 years

H Pipin Arifin, 31 years 


\section{Shirkah Author Guidelines}

Shirkah currently offers two routes to submit manuscripts. We highly recommend to submit the articles which are made using OJS (Open Journal System). Feel free register as author soon through visiting http:// shirkah.or.id/index.php/home/user/register. The authors may directly send their manuscripts, along with their resume, to shirkahiainsurakarta@ gmail.com. Please prepare your manuscripts, using following guidelines:

1. Manuscript must be written in English. Submitted articles should not have been published or be under review for publication with another journal.

2. Manuscript's length is about $15-20$ pages, typed in one-half spaced on A4-paper size.

3. Manuscript must include an $150-200$ word abstract and keywords.

4. Manuscript must be arranged as follows: Title, Name of Author, E-mail address, Abstract, Keywords, Introduction (including method if any), Discussion, Conclusion, References.

5. Manuscript's titles not more than ten words.

6. Manuscript must be submitted in Microsoft Word or RTF.

7. Arabic words should be transliterated according to the style of International Journal of Middle Eastern Studies.

8. Manuscript references are preferably derived from the up-to-date references.

9. The author's resume should be submitted separately, consisting of at least full name, institutional address, phone number, areas of studies, and recent publications (if any).

10. Shirkab use APA Style 6th edition (2010) as reference format writing. We suggest the use of a reference manager software such as Mendeley, Zotero, and Endnote at templating the citation style. APA Style to be used is as follows: 


\section{Book with single author}

Swann, G. M. Peter. (2014). The Economics of Innovation an Introduction. Cheltenhum \& Northampton: Edward Elgar.

in-text citation: (Swann, 2014)

\section{Articles in reference books}

Alatas, S. F. (2006). Islam and the Science of Economics in Abu Rabi', I.M. The Blackwell Companion to Contemporary Islamic Thought. USA: Willey-Blackwell (pp. 587-606).

in text citation: (Alatas, 2006)

\section{E-Book}

Hackett, Rosalind (2007). "Religous Dimentions of War and Peace: Introduction.” Dalam Gerrie ter Haar dan Yoshio Tsuruoka (Ed.), Religion and Society: An Agenda for the 21st Century (h. 3-6). Retrieved from http:// brill.nl.

in text citation: (Hackett, 2006)

\section{Master's thesis, from a commercial database}

McNieI, D. S. (2006). Meaning through narrative: A personal narrative discussing growing up with an alcoholic mother (Master's thesis). Available from ProQuest Dissertations and Theses database. (UMI No. 1434728)

in text citation: (Mc Niel, 2006)

\section{Doctoral dissertation, from an institutional database}

Adams, R. J. (1973). Building a foundation for evaluation of instruction in higher education and continuing education (Doctoral dissertation). Retrieved from http://www.ohiolink.edu/etd/

in text citation: (Adams, 1973) 


\section{Doctoral dissertation, from the web}

Bruckman, A. (1997). MOOSE Crossing: Construction, community, and learning in a networked virtual world for kids (Doctoral dissertation, Massachusetts Institute of Technology). Retrieved from http:/www-static. cc.gatech.edu/--asb/thesis/

in text citation: (Bruckman, 1997)

\section{Journal article with No DOI}

Bourkhis, K., and Nabi, M. S. (2013). Islamic and conventional banks' soundness during the 2007-2008 financial crisis. Journal Metrics, 22(2), 68-77.

in-text citation: (Bourkhis \& Nabi, 2013).

\section{Journal article with DOI}

Ichwan, M. (2012). The Local Politics Of Orthodoxy: The Majelis Ulama Indonesia in the Post-New Order Banten. Journal Of Indonesian Islam, 6(1), 166-194. doi:http://dx.doi.org/10.15642/JIIS.2012.6.1.166-194

In text citation : (Ichwan, 2012)

\section{Abstract as citation}

Hasan, N. (2012). Islamist Party, Electoral Politics And Da'wah Mobilization Among Youth : The Prosperous Justice Party (PKS) in Indonesia. Journal of Indonesian Islam, 6(1), 17-47. Abstract from http:// jiis.uinsby.ac.id/index.php/jiis/article/view/97

in text citation : (Hasan, 2012)

\section{Mass media article}

Sahal, Akhmad (2014, March 2). Kiai Sahal dan Realisme Fikih.Tempo Magazine, p. 120.

in text citation : (Sahal, 2014) 


\section{Research report}

Fisher, B. S., Cullen, F. T., \& Turner, M. G. (2000). The Sexual Victimization of College Women. Research Report.

in text citation : (Fisher, Cullen, Turner, 2000)

\section{Monograph}

Routray, Bibhu Prasad (2013), National Security Decision-Making in India (RSIS Monograph No. 27). Singapura: Rajaratnam School of International Studies.

in text citation : (Routray, 2013)

\section{Proceeding article}

Sudibyakto, Hizbaron, D.R., \& Jati, R (Ed.) (2009), Proceeding International Seminar Disaster Theory, Research and Policy. International seminar held by Sekolah Pascasarjana, Universitas Gajahmada, Yogyakarta, 8-9 Desember 2009.

in text citation : (sudibyakto and Jati, 2009)

\section{Paper conference/seminar/symposium}

Janutama, Herman Sinung (2011). "Kraton dan Hubungan Antar Agama." Paper presented in Seminar Kraton dan Panatagama held by Center for the Study of Islam and Social Transformation (CISForm), Yogyakarta, 17 November.

$$
\text { in text citation :(Janutama, 2011) }
$$

\section{Online article in web}

Shiva, (2006, February). Bioethics: A Third World Issue. Native-web. Diperoleh dari http://www.nativeweb.org/ pages/legal/shiva.html 


\section{in text citation : (Shiva, 2006)}

\section{Online research report}

Kessy, S. S. A., \& Urio, F M. (2006). The contribution of microfinance institutions to poverty reduction in Tanzania (Research Report No. 06.3). Retrieved from Research on Poverty Alleviation website: http://www. repoa.or.tz /documents_storage/Publications/Reports/06.3_Kessy_and_ Urio.pcif

in text citation : (kessy and urion, 2006)

\section{Holy book}

Qur an, $2(25)$

In text citation : (Q. al-Baqarah 2:25).

\section{Encyclopaedia}

Graycar, Adam (1992). Social Welfare Policy. Dalam Mary Hawkesworth dan Maurice Kogan (Ed.), Encyclopedia of Government and Politics (Vol. 1). London: Routledge.

in text citation : (Graycar, 1992)

\section{Interview}

Sultan Hamengkubuwono X (interview, 2011, April 19)

in text citation : (Hamengkubuwono, 2011)

\section{Documentary film}

Steijlen, Fridus (2008). A Day in the Life of Indonesia [documentary film, 58 minutes]. Leiden: KITLV Press.

in text citation : (Steijlen, 2008) 
Vol. 4 No. 3, September - December 2019 